Добруха Л.Г.

Національний транспортний

університет

E-mail: L-dobrukha@ukr.net

\section{ІНДЕКС ЕФЕКТИВНОСТІ ЛОГІСТИКИ ЯК ІНТЕРАКТИВНИЙ ІНСТРУМЕНТ ПОРІВНЯЛЬНОГО АНАЛІЗУ ЕФЕКТИВНОСТІ ТРАНСПОРТНОЇ СИСТЕМИ}

УдК 656.1:658.3.005.95/.96

Добруха Л.Г. «Індекс ефективності логістики як інтерактивний інструмент порівняльного аналізу ефективності транспортної системи»

У статті розглянуто декілька показників формування загального індексу LPI, на значення яких впливає якість логістичних послуг, щзо безпосередньо обумовлено ефективністю, своєчасністю, професійністю надання автотранспортних послуг з перевезень пасажирів та вантажів і позначається на іміджі держави, як комериійного партнера на міжнародному ринку.

Об'єкт дослідження: прочес надання логістичних послуг в умовах глобалізації автоперевезень пасажирів та вантажів.

Мета роботи: аналіз та дослідження впливу показника «якості $і$ компетентності логістичних послуг» на міжнародні індекси і рейтинг краӥни.

Науковою новизною проекту є запропонований підхід щзодо здійснення в он-лайн режимі моніторингу компетентності виконавців автотранспортних послуг, в тому числі водїв, який не має аналогів в Україні $i$ відповідає світовим вимогам і стандартам галузі.

Методи досліджень - статистичний аналіз, метод Делфі, методи SWOT-аналізу, SMART-аналізу та STEP - аналізу, множинного корелячійного аналізу, прогнозування.

В роботі розглянуто питання впровадження інформаџійної системи управління професійною компетентністю (Реєстр водіїв), як «доступу до професії» на ринку комериійних автоперевезень.

Прогнозований вплив проекту на розвиток автотранспортної та суміжних галузей: введення в дію інформаційної система управління професійною компетентністю дозволить покращчти умови для імплементації Угоди про Асоиіацію у частині запровадження початкової кваліфікації $i$ періодичноі підготовки водіїв деяких видів автомобільного транспорту для перевезення вантажів або пасажирів, щзо в свою чергу позитивно вплине на підвищення ефективності та безпеки переміщення товарів украӥнськими комерційними автотранспортними операторами у міжнародному сполученні, на підвищення рівню логістичних послуг, та як результат показника Якості та Компетентності логістичних послуг при формуванні загального індексу LPI Украӥни, і як наслідок підвищення рівню конкурентоспроможності, розвитку міжнародної торгівлі, привабливості інвестиційного клімату, а значить іміджу і рейтингу краӥни. Ключові слова: логістика, транспортні системи, ефективність, інноваџї, міжнародні перевезення вантажів, митниця, транспортна інфраструктура, реєстр, інтелектуальні транспортні системи, компетентність

Добруха Л.Г. «Индекс эффективности логистики как интерактивный инструмент сравнительного анализа эффективности транспортной системы»"

B статье рассмотрено ряд показателей формирования общего индекса LPI, на значение которых влияет качество логистических услуг, что непосредственно обусловлено эффективностью, своевременностью, профессионализмом оказываемых автотранспортных услуг по перевозке грузов и пассажиров, и отражается на имидже государства, как коммерческого партнера на международном рынке.

Объект исследования: процесс предоставления логистических услуг в условиях глобализации автоперевозок грузов и пассажиров.

Цель работы: анализ и исследование влияния показателя «качества и компетентности логистических услуг» на международные индексы и рейтинг страны.

Научной новизной проекта является предложенный подход по осуществлению в режиме он-лайн мониторинга компетентности исполнителей автотранспортных услуг, в том числе водителей, не имеющий аналогов в Украине и соответствующий мировым требованиям и стандартам отрасли.

Методы исследований - статистический анализ, метод Дельфи, методы SWOT-анализа, SMARTанализа и STEP - анализа, множественного коррелячиионого анализа, прогнозирования.

В работе рассмотрены вопросы внедрения информационной системы управления профессиональной компетентностью (Реестр водителей), как «доступа к профессии» на рынке коммерческих автоперевозок.

Прогнозируемое влияние проекта на развитие автотранспортной и смежных отраслей: введение в действие информационной системы управления профессиональной компетентностью позволит улучшить условия для имплементации Соглашения об ассоџиаџии в части введения начальной квалификации и периодической подготовки водителей некоторых видов автомобильного транспорта для перевозки грузов или пассажиров, что в свою очередь положительно повлияет на повышение эффективности и безопасности перемещения товаров украинскими коммерческими автотранспортными операторами в международном 
сообщении, повышение уровня логистических услуг и как результат показателя качества и компетентности логистических услуг при формировании общего индекса LPI Украины, и как следствие повышение уровня конкурентоспособности, развития международной торговли, привлекательности инвестиционного климата, а значит имиджа и рейтинга страны.

Ключевые слова: логистика, транспортные системы, эффективность, инновации, международные перевозки грузов, таможня, транспортная инфраструктура, реестр, интеллектуальные транспортные системы, компетентность.

Dobrukha L.G. «Index of logistics efficiency as an interactive tool for comparative analysis of the transport system efficiency"

The paper considers a number of indicators patterning overall LPI index, which is influenced by the logistics services quality, directly determined by the efficiency, delivery timeliness and professionalism as regards road haulage and passenger transport services, and affects the image of the state as a commercial partner at the international market.

Object of research: the process of logistics services rendering in the context of road haulage and passenger transport globalization.

Purpose of work: to analyze and study the impact of "quality and logistics services competence" indicator on international subindicators and the country's rating.

Scientific novelty of the project is the proposed approach for the implementation of on-line monitoring of the road transport services executors' competence, including drivers, which has no analogues in Ukraine and meet international requirements and standards of the industry.

Research methods: Delphi method, statistical analysis, methods of SWOT analysis, SMART analysis STEP analysis, multiple correlation analysis, forecasting.

The paper explores implementation of information system for professional competence management (Drivers Register) as "access to profession" on the commercial road transport market.

Projected impact of the project on the motor transport and related industries development: the introduction of an information system for professional competence managing will improve the conditions for the implementation of the Association Agreement regarding introduction of initial qualifications and periodic training for drivers of certain types of vehicles for the goods or passengers transport, which in turn will positively affect improvement of goods movement efficiency and safety by international commercial road transport operators of Ukraine, increasing logistics services level and thus of the competence and quality indicator of logistics services measuring overall LPI of Ukraine, resulting in upgrade of competitiveness level, development of international trade, attractive investment climate, and therefore the image and rating of the country.

Keywords: logistics, transport system, efficiency, innovation, international transport of goods, customs, transport infrastructure, registry, intelligent transport systems, competence.

\section{Актуальность проблеми.}

В сучасну еру розвитку міжнародної торгівлі комунікація між учасниками процесу стає дедалі складнішою так як потребує координації більшої низки питань. Мережі постачання перетинають країни та регіони. Торгівля стала цілодобовим 24/7 бізнесом, і хороші показники торгівлі вимагають інтеграції не тільки у галузі автомобільних, залізничних і морських перевезень, але й у сфері телекомунікацій, фінансових ринків та обробки інформації, тобто всіх складових транспортно-технологічної системи доставки вантажів. Неефективні або нераціональні транспортно-технологічні системи, логістика та пов'язана з торгівлею інфраструктура, можуть серйозно перешкодити здатності країни конкурувати в глобальному масштабі.

За даними Організації економічного співробітництва та розвитку (OECD) очікується, що протягом наступних 30 років, обсяги міжнародних вантажних перевезень збільшаться на $400 \%$. Із зростанням населення, яке, за прогнозами, досягне у 2050 році 10 мільярдів чоловік, збільшаться так само і потреби в міжнародних поїздках і переміщенні пасажирів у містах.[1]. Тому суспільству необхідні стабільні рішення для пом'якшення цього зростаючого попиту переміщення товарів і пасажирів між містами та логістичними центрами за допомогою вдосконалення існуючих $\mathrm{i}$ розвинення інноваційних інтелектуальних систем. [5]

Будь-який товар проходить обробку та свій шлях до користувача. Наприклад, на мить уважно подивимось на свій смартфон. Скляний екран. Кнопка оснащена розпізнаванням відбитків пальців. Об'єктив камери, ліхтарик, мікрофон і динамік. 
Кожен з цих та інших компонентів, в тому числі мікросхеми, процесори, акумулятори, поставляються незалежно один від одного компаніями, розташованими по всьому світу, і збираються в готовий продукт на заводах, наприклад у Китаї. Будь-який смартфон, який ми купуємо та його компоненти, ймовірно, кілька разів проходили через митницю, переміщувалися в різних країнах і на різних континентах і проходили крізь руки незліченної кількості працівників. Цілком зрозуміло, що все це стає можливим завдяки логістиці. Логістика, яка фактично $є$ мережею послуг, що підтримує фізичне переміщення товарів у межах країни та за кордоном, являє собою індустрію у 4,3 трлн. доларів США і впливає майже на кожну країну світу [1].

Безумовно логістика включає в себе безліч видів діяльності, включаючи транспортування, складування, брокерські послуги, експрес-доставку, операції у терміналах і навіть управління даними та інформацією. Отже наскільки ефективним $\epsilon$ переміщення товарів крізь ці системи до кінцевих пунктів призначення, $є$ ключовим фактором, що визначає торгові можливості країни. Так директор напрямку Макроекономіка, торгівля та інвестиційна світова практика в Групі Світового банку, Керолайн Фройнд стверджує: “Логістику можна розглядати як основу світової торгівлі. [13] I оскільки ланцюжки поставок стають все більш глобально розосередженими, якість логістичних послуг країни може визначити, чи може вона брати участь у світовій економіці".

\section{Аналіз останніх досліджень}

Аналіз останніх досліджень і публікацій, в яких започатковано вирішення даної проблеми. Теоретичні і практичні аспекти взаємозв'язку між вантажними, пасажирськими перевезеннями та економічною діяльністю, останніми роками $\epsilon$ об'єктом багатьох досліджень як вітчизняних (Прокудін Г.С., Дудник О.С., Чупайленко О.А, 2015) [14], (Процик О.П., Корчменюк С.В., 2015) [15], (Шраменко Н.Ю., 2010) [18-20] ( Карий О. І., Подвальна Г. В., 2017) [21], так і зарубіжних науковців, дослідників, експертів міжнародних організацій та установ (David Bannister and Dominic Stead, 2002), [17], (Michele Acciaro, Alan McKinnon, 2013) [4], International transport Forum [3], Світовий банк [16], Organisation for Economic Co-operation and Development, [1], та інші.

Особливої уваги заслуговує новітній підхід Світового Банку щодо визначення змін, які відбуваються у цієї галузі , який запровадив щорічний аналіз індексу ефективності логістики [8].

Метою статті є дослідження щодо впливу змін в покращенні показників ефективності транспортно-технологічної системи доставки вантажів на показники індексу ЛПІ та економічної привабливості країни в цілому.

\section{Виклад основного матеріалу дослідження.}

Історично існує тісна статистична кореляція між зростанням валового внутрішнього продукту (ВВП) і зростанням транспорту, як пасажирським, так і вантажним. Численні дослідження і практика свідчать про те, що обсяги вантажних та пасажирських перевезень наземним транспортом (автодорожні та залізничні) значно корелюють з ВВП, а вантажні перевезення безпосередньо прив'язані до ланцюга постачання (як готових, так і проміжних товарів), i, як наслідок, обсяги перевезення вантажів відображають зростання продажів або активності у виробничому секторі.

\section{Порівняльний аналіз Ефективності Логістики.}

Оскільки торгівля та логістика стосуються багатьох областей економіки, може бути важко отримати повну картину продуктивності країни. 3 цієї точки зору, цікавим здається розглянути індекс ефективності логістики (LPI), Групи Світового банку, який є частиною 
дворічного звіту Connecting to Compete, оцінює країни за рядом показників. LPI - Індекс ефективності логістики - це інтерактивний інструмент порівняльного аналізу, створений для того, щоб допомогти країнам визначити проблеми, з якими вони стикаються у своїй діяльності в області торгової логістики, а також можливості, які з'являються, і те, що вони можуть зробити для поліпшення своїх показників. LPI 2018 дозволяє проводити порівняння в 160 країнах. LPI заснований на всесвітньому опитуванні операторів на місцях (глобальні експедитори та експрес-перевізники), який дає зворотний зв'язок про «доброзичливості» логістики країн, в яких вони працюють, і тих, з якими вони торгують. Вони поєднують в собі глибокі знання про країни, в яких вони працюють, 3 обгрунтованими якісними оцінками інших країн, в яких вони торгують, i досвідом глобальної логістичної середовища. Відгуки операторів доповнюються кількісними даними про ефективність ключових компонентів логістичного ланцюжка в країні роботи.

Індекс, який враховує такі фактори, як, наприклад, компетенція з логістики та професійність; якість інфраструктури, пов'язаної 3 торгівлею; вартість міжнародних перевезень і регулярність, з якою поставки досягають свого призначення вчасно, допомагає урядам визначати свій прогрес в часі у порівнянні з аналогічними країнами.

Таким чином, LPI складається як з якісних, так і кількісних показників і допомагає створити профілі, так званої "дружності" логістики або орієнтації на інтереси цих країн. LPI вимірює продуктивність по всьому ланцюжку логістичних поставок всередині країни i пропонує дві різні перспективи: міжнародну і внутрішню.

Визначення LPI передбачає два напрямки перспективного аналізу рівня ефективності господарсько-економічної діяльності країни, на підставі опитувань фахівців і професіоналів в області логістики :

- Економічна активність всередині країни - "Внутрішній LPI" означає кількісну і якісну оцінку послуг країни, що надаються фахівцями з логістики, які працюють в країни. Цей компонентний індекс надає детальну інформацію про інфраструктуру країни, якість послуг провайдерів, прикордонні процедури і надійності ланцюжка поставок.

- Економічна активність за межами країни - “Міжнародний LPI” передбачає оцінку послуг країни, що надаються фахівцями з логістики за межами країни. Цей компонентний індекс надає якісну інформацію про те, як торгові партнери країни сприймають ефективність і якість іï̈ логістичних послуг.

Внутрішній LPI надає як якісні, так і кількісні оцінки країни фахівцями $з$ логістики, які працюють в ній. Індекс включає в себе детальну інформацію про логістичне середовище, основні логістичні процеси, установи, а також дані про час та витрати. Внутрішній LPI докладно розглядає логістичну середу в 100 країнах. [7] 3 цією метою опитані фахівці 3 логістики оцінюють умови логістики в своїх країнах. Така внутрішня оцінка містить більш детальну інформацію про логістичне середовище країн, основні логістичні процеси й

Графік 1. Оцінка індексу ефективності логістики України, карта країни

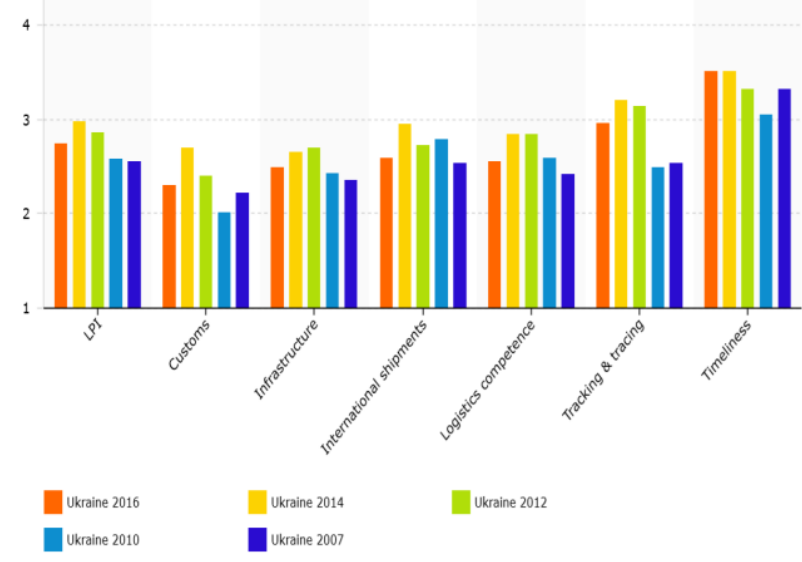
інститути, а також дані про час і відстань. Даний підхід враховує логістичні обмеження всередині країн, а не тільки вузлові точки консолідації, навантаження і відправлення товарів, такі як порти або кордони. Для вимірювання ефективності використовуються чотири основних детермінанта загальної ефективності логістики:

- Інфраструктура,

- Послуги,

- Прикордонні процедури і час, i

• Надійність ланцюга постачання. 
На графіку 1 наглядно відображений рейтинг Індексу ефективності Логістики України в динаміці по роках з 2007 по 2016 рр. у урахуванням показників (таблиця даних 1) щодо стану Інфраструктури, Компетентності у галузі логістики, Міжнародних перевезень, Митниці, Можливості відстеження (вантажів).

Таблиця 1

Показники. Індексу Ефективності Логістики Україна 2007-2016р

\begin{tabular}{|c|c|c|c|c|c|c|c|c|c|}
\hline Country & Year & $\begin{array}{c}\text { LPI } \\
\text { Rank }\end{array}$ & LPI Score & $\begin{array}{c}\text { Customs } \\
?\end{array}$ & $\begin{array}{c}\text { Infrastructure } \\
?\end{array}$ & $\begin{array}{c}\text { International } \\
\text { shipments } \\
?\end{array}$ & $\begin{array}{c}\text { Logistics } \\
\text { competence } \\
?\end{array}$ & $\begin{array}{c}\text { Tracking \& } \\
\text { tracing } \\
?\end{array}$ & $\begin{array}{c}\text { Timeliness } \\
?\end{array}$ \\
\hline Ukraine & 2014 & 61 & 2.98 & 2.69 & 2.65 & 2.95 & 2.84 & 3.20 & 3.51 \\
\hline Ukraine & 2012 & 66 & 2.85 & 2.41 & 2.69 & 2.72 & 2.85 & 3.15 & 3.31 \\
\hline Ukraine & 2016 & 80 & 2.74 & 2.30 & 2.49 & 2.59 & 2.55 & 2.96 & 3.51 \\
\hline Ukraine & 2010 & 102 & 2.57 & 2.02 & 2.44 & 2.79 & 2.59 & 2.49 & 3.06 \\
\hline Ukraine & 2007 & 73 & 2.55 & 2.22 & 2.35 & 2.53 & 2.41 & 2.53 & 3.31 \\
\hline
\end{tabular}

Міжнародна Система Показників LPI

Міжнародна система показників використовує шість ключових параметрів для оцінки ефективності країн, а також відображає загальний індекс LPI. Система показників дозволяє проводити порівняння у світовому масштабі (з можливістю відображення найбільш ефективної у світі країни) та в масштабі регіонів або група за рівнем доходів (з можливістю відображення кращої позиції регіону або групи за рівнем доходів) за шістьма показниками та загальним індексом LPI. [12]

Індекс або показник ефективності Логістики (LPI) - це середньозважена величина балів країни за шістьма ключовими вимірами:

1) Ефективність процесу оформлення (тобто швидкість, простота i передбачуваність формальностей) органами прикордонного контролю, включаючи митні органи;

2) Якість інфраструктури, яка пов'язана $з$ торгівлею та транспортом (наприклад, портів, залізниць, автодоріг, інформаційних технологій);

3) Простота організації перевезень за конкурентними цінами;

4) Компетентність та якість логістичних послуг (наприклад, транспортні оператори, митні брокери);

5) Здатність відстежування та контролю за переміщенням вантажів;

6) Своєчасність поставок вантажів у пункти призначення протягом запланованого або очікуваного часу доставки. Результати показників демонструють порівняльну продуктивність усіх країн (світу), регіональних та груп за рівнем доходів. На нижче наведеному графіку 2 бачимо рівень розвитку логістики за зазначеними показниками (таблиця даних 2) станом на 2018 рік. 


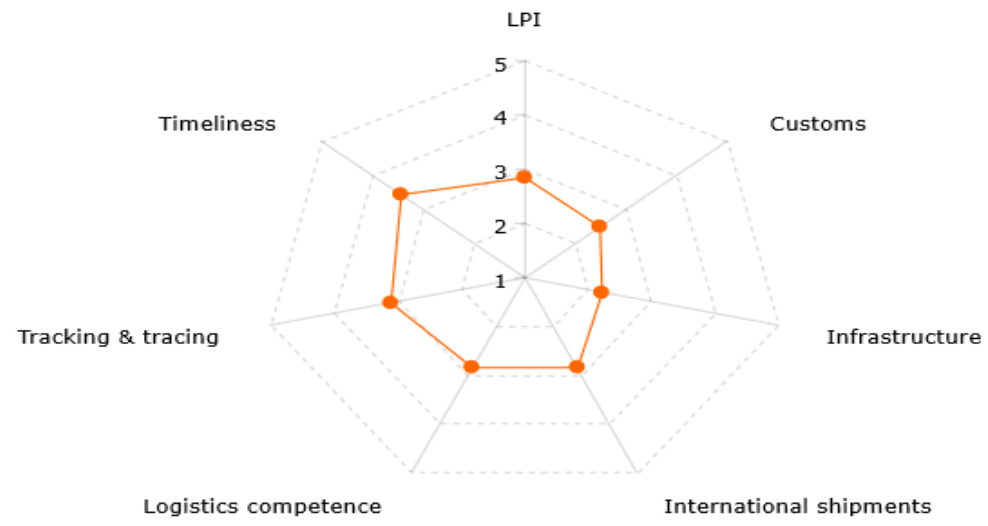

Ukraine 2018

Графік 2. Рівень розвитку логістики України 2018р.

Таблиця 2

Показники .Індексу Ефективності Логістики України 2018p

\begin{tabular}{|c|c|c|c|c|c|c|c|c|}
\hline$\underline{\text { Country }}$ & Year & $\underline{\underline{\text { LPI }}}$ & $\underline{\underline{\text { LPI }}}$ & Customs & Infrastructure & $\frac{\text { International }}{\text { shipments }}$ & $\begin{array}{l}\underline{\text { Logistics }} \\
\text { competence }\end{array}$ & $\begin{array}{l}\text { Tracking } \\
\text { \& tracing }\end{array}$ \\
\hline
\end{tabular}

$\begin{array}{lllllllll}\text { Ukraine } 2018 & 66 & 2.83 & 2.49 & 2.22 & 2.83 & 2.84 & 3.11 & 3.42\end{array}$

Source : https://lpi.worldbank.org/international/scorecard/radar/254/C/UKR/2018\# [6]

Німеччина впевнено займає першу позицію у списку, за показниками індексу LPI 4,20, Інфраструктури 4.37, Компетентності у галузі логістики 4.31, міжнародних перевезень 3.86.

На даному графіку 3 можемо спостерігати динаміку змін індексу ефективності логістики України у порівнянні до лідеру регіонального рейтингу Німеччини, згідно до зазначених показників Таблиця 3.

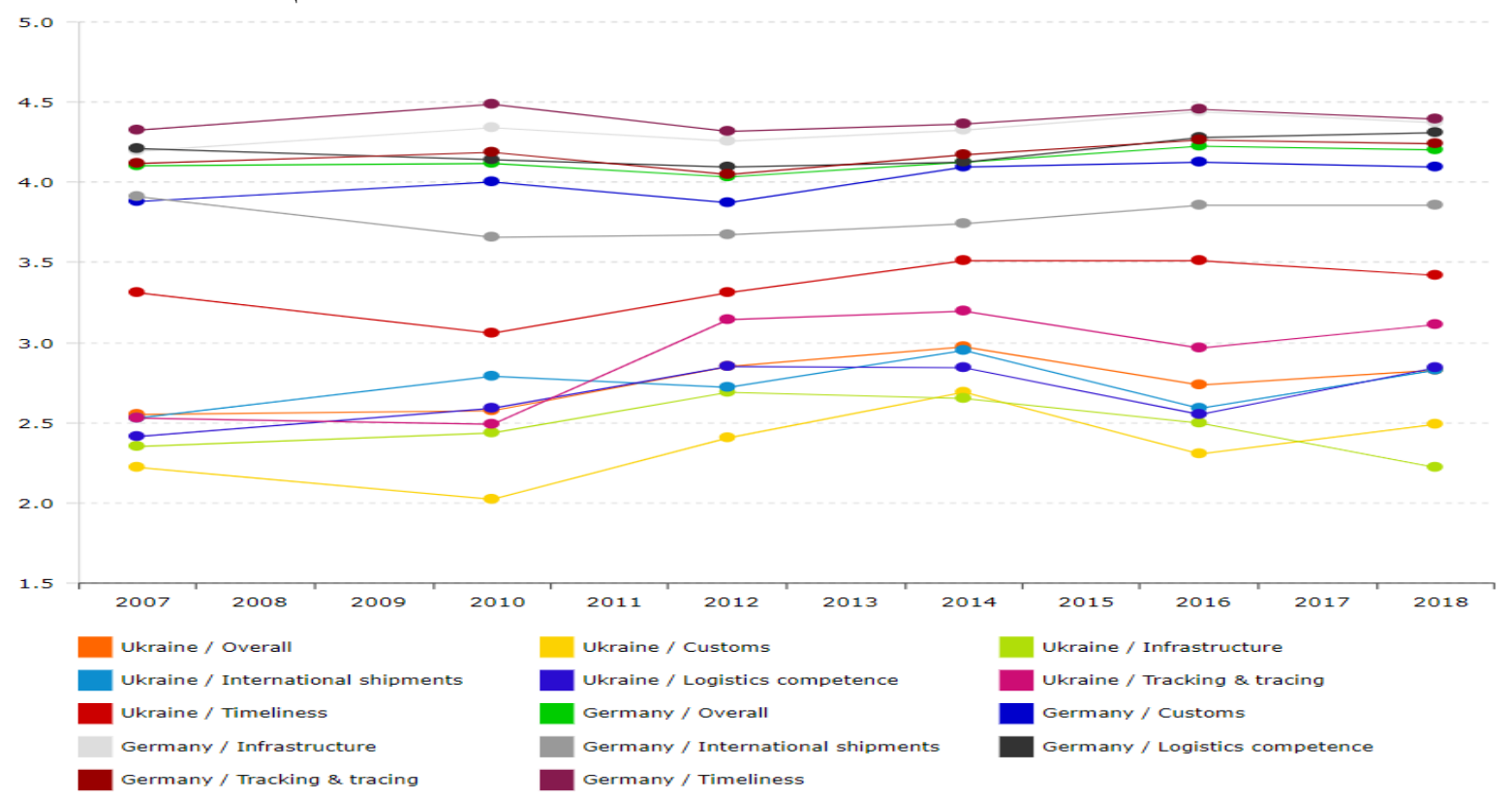

Графік 3. Україна у порівнянні з лідером региону за ефіективністю (Німеччина) за 2007-2018р. 
Показники LPI Україна і Німеччина за 2007-2018p.

\begin{tabular}{|c|c|c|c|c|c|c|c|c|c|}
\hline Country & Year & $\begin{array}{c}\text { LPI } \\
\text { Rank }\end{array}$ & LPI Score & $\begin{array}{c}\text { Customs } \\
?\end{array}$ & $\begin{array}{c}\text { Infrastructure } \\
?\end{array}$ & $\begin{array}{c}\text { International } \\
\text { shipments } \\
?\end{array}$ & $\begin{array}{c}\text { Logistics } \\
\text { competence } \\
?\end{array}$ & $\begin{array}{c}\text { Tracking \& } \\
\text { tracing } \\
?\end{array}$ & $\begin{array}{c}\text { Timeliness } \\
?\end{array}$ \\
\hline Germany & 2018 & 1 & 4.20 & 4.09 & 4.37 & 3.86 & 4.31 & 4.24 & 4.39 \\
\hline Ukraine & 2018 & 66 & 2.83 & 2.49 & 2.22 & 2.83 & 2.84 & 3.11 & 3.42 \\
\hline
\end{tabular}

Група Світового банку проводить таку якісну оцінку країн за вище зазначеними критеріями кожні два роки з моменту виходу першого випуску видання «З'єднуватися щоб конкурувати» (Connecting to Compete) в 2007 році. Протягом зазначеного часу спостережень, виявляється закономірним, що країни з високим рівнем доходу, особливо в Західній Європі, незмінно стають світовими лідерами в області логістики. Фактично, показник LPI в країнах з високим рівнем доходу в середньому на $48 \%$ вище, ніж в країнах 3 низьким рівнем доходу. 330 країн з найвищими показниками $24 \epsilon$ членами Організації економічного співробітництва та розвитку (ОЕСР). «Ми бачимо, що більшість країн вкладають кошти в реформи, пов'язані з логістикою, особливо в галузі створення інфраструктури та сприяння торгівлі», - пояснює Жан Франсуа- Арвіс, економіст в Групі Світового банку і співавтор доповіді. «Не дивлячись на такі ж зусилля 3 модернізації послуг у країнах, що розвиваються, останні стикаються з багатьма іншими проблемами. Це пояснює постійний розрив між країнами 3 високим і низьким рівнем доходів 3 точки зору ефективності логістики ». [8 ]

Однак, один тільки дохід не є єдиним визначальним фактором для показника LPI країни. Наприклад, такі країни як В'єтнам, Таїланд, Руанда, Китай і Індія (як свідчать нижченаведені дані) випереджають свої групи країн, сформовані за показниками доходів. Як правило, ці країни, мають доступ до морських портів або великих міжнародних транспортних вузлів.

Яким же чином пов'язані доходи країн та логістичні показники? Країни з високим рівнем доходів, як правило, перевершують країни 3 низьким рівнем доходу у сфері логістики. Але дохід, як відмічалось вище, не є єдиним чинником, що визначає. Як бачимо на цьому графіку 4 - країни, які знаходяться далі від лінії тренду, мають більш чи менш високі показники в порівнянні з їх групою доходів.

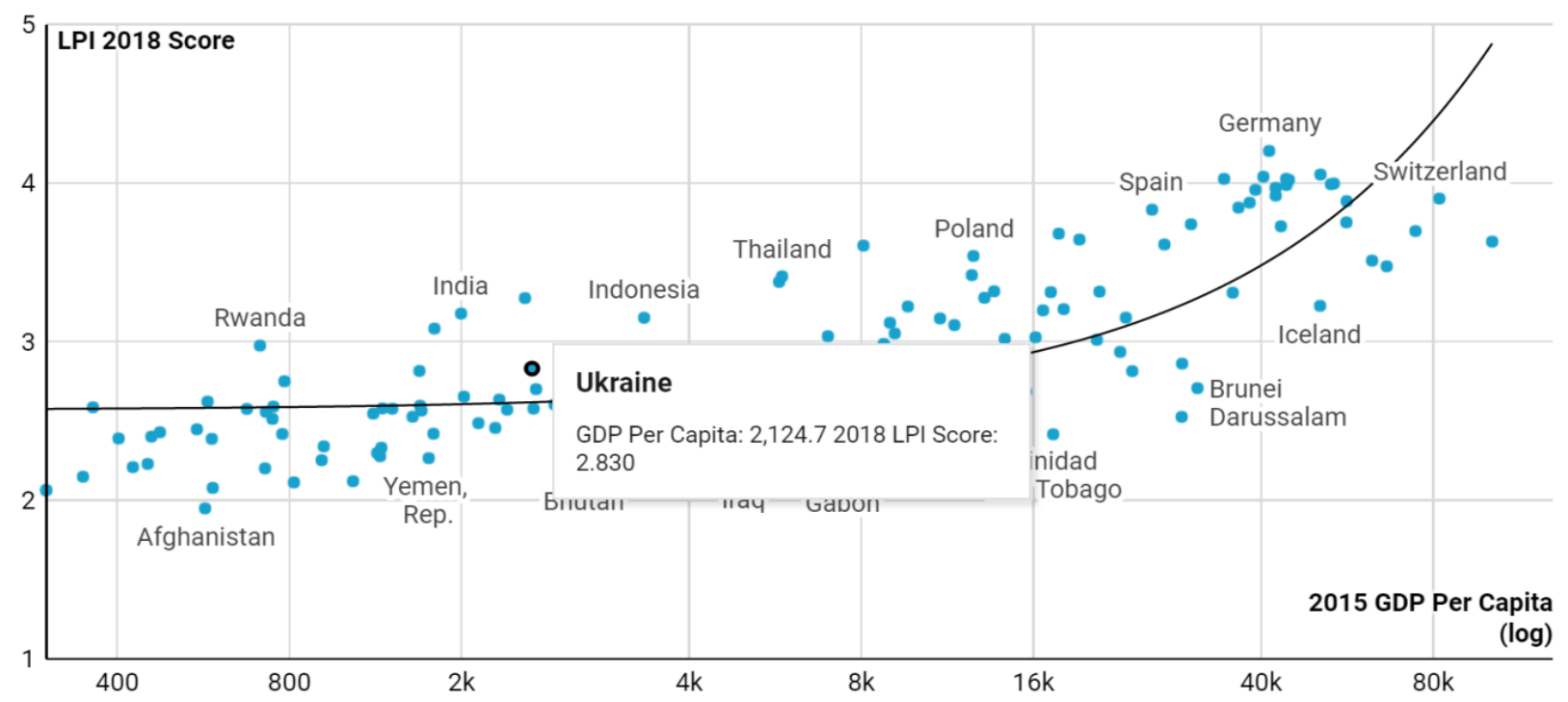

Графік 4. Світовий Рейтинг LPI 2018

Source: 2018 Logistics Performance Index, World Bank Group 
За даними Групи Світового Банку, рейтинг Україні у 2018 році, щодо рівню ефективності логістики, становить 2.830 при показниках ВВП на душу населення в нашій країні 2,124.7. Таким чином, як бачимо, за індексом ефективності логістики Україна посідає 66 місце (таблиця даних 4 ) після В'єтнаму, Малайзії, Руанди, Бахрейну, Філіппін та багатьох інших країн.

Для окремих країн, система логістики $є$ ключовим фактором їх економічного зростання і конкурентоспроможності. Неефективна логістика підвищує вартість ведення бізнесу та зменшує потенціал інтеграції з глобальними ланцюгами створення вартості (глобальними виробничо-збутовими ланцюжками). Пов'язані втрати та збитки можуть виявитися особливо важкими для країн, що розвиваються, які намагаються конкурувати на світовому ринку. Уряди, представники бізнесу, економісти, дослідники, викладачі можуть використовувати LPI також, для того щоб краще розуміти зв'язок між логістикою, торгівлею i економічним зростанням, а також сприяти просуванню політик для впровадження 3 метою конкуренції на глобальному рівні. Результати досліджень LPI $\epsilon$ підтвердженням в цифровому вираженні того, наскільки легко чи складно в досліджуваних країнах перевозити промислові товари - стандартні готові вироби, упаковані в вантажні місця.

Таблиця 4

\section{Україна в Світовому Рейтингу LPI 2018}

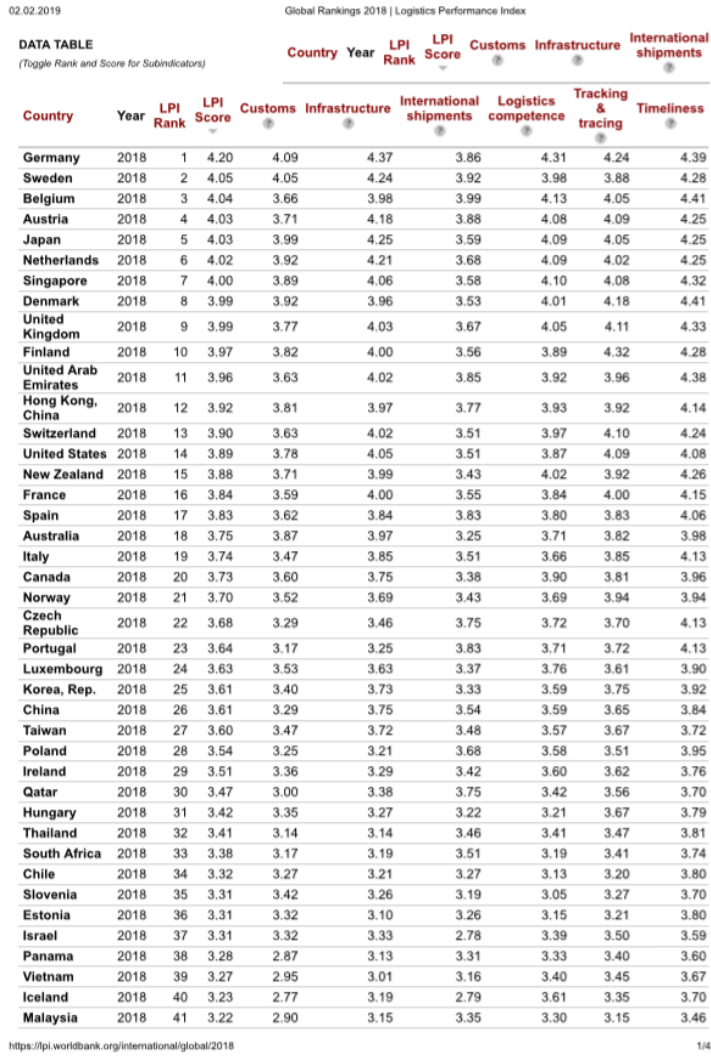

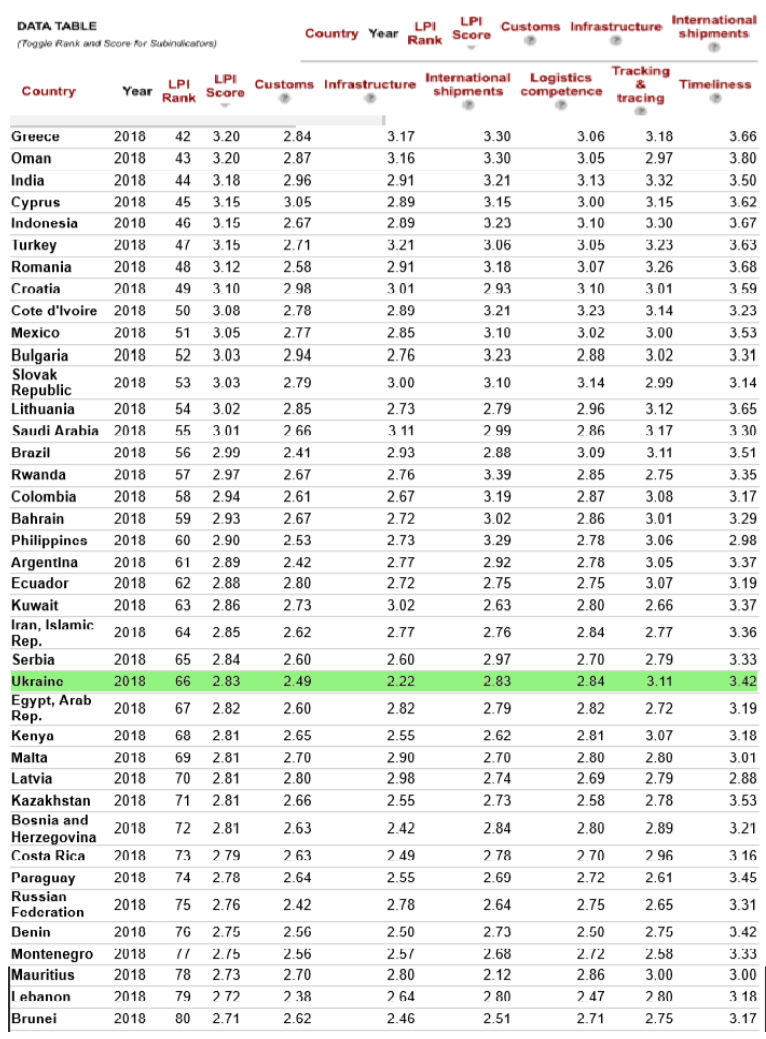

\section{Компетентність та якість логістичних послуг}

Розглянемо один 3 ключових показників формування загального індексу LPI, «Компетентність та якість логістичних послуг» (від $1=$ низький до $5=$ високий) 3 метою порівняння у світовому масштабі (таблиця даних 5). Як свідчать наведені дані, зміни параметрів даного показника, залежно від рівню розвинення певної галузі, безпосередньо впливають на позицію країни в міжнародному рейтингу. Країна з найвищою оцінкою у світі - Німеччина, величина 4,31. Країна $з$ найнижчим показником у світі - Афганістан, 
значення якого становить 1,92 . Показник рівня компетентності та якості логістичних послуг в Україні становить 2,84.

Таблиця 5

Показники компетентності та якості логістичних послуг за 2018p.

\begin{tabular}{|l|l|l|}
\hline \multicolumn{1}{|c|}{ Країна } & \multicolumn{1}{|c|}{$\begin{array}{c}\text { Рейтинг } \\
\text { LPI }\end{array}$} & $\begin{array}{c}\text { Компетентність та якість логістичних } \\
\text { послуг }\end{array}$ \\
\hline Німеччина & 1 & 4,31 \\
\hline Нідерланди & 6 & 4,09 \\
\hline Велика Британія & 9 & 4,05 \\
\hline Франція & 16 & 3,84 \\
\hline Чеська республіка & 22 & 3,72 \\
\hline Польща & 28 & 3,58 \\
\hline Хорватія & 49 & 3,10 \\
\hline Литва & 54 & 2,96 \\
\hline Україна & 66 & 2,84 \\
\hline Афганістан & 160 & 1.92 \\
\hline
\end{tabular}

Загальновідомо, що якість будь-яких послуг та логістичних послуг в тому числі прямо пропорційно залежить від професійної компетентності фахівців середньої та вищої ланки всього логістичного ланцюжка. Особливе місце займає спеціальна професійна підготовка транспортних операторів, а саме менеджерів і водіїв, компаній зайнятих в наданні послуг комерційних автоперевезень пасажирів і вантажів, в національному та міжнародному сполученні, (в тому числі небезпечних, негабаритних, швидкопсувних вантажів та інших типів вантажів).

\section{Результати досліджень}

В результаті аналізу досліджень численних досліджень простежується закономірність: країни з високим рівнем професійної компетентності кадрів пропонують більш якісні логістичні послуги і більш ефективні автоперевезення, особливо в Центральній і Західній Свропі, і впевнено тримають лідируючі позиції на світовому рівні.

Європейське дослідження причин нещасних випадків за участю вантажівок (ЕTAC) демонструють, що понад 85\% аварії були пов'язані з помилкою людини. [10] Аналогічним чином, "Дослідження причин ДТП з вантажівками" (LTCCS) підтверджує, що основною причиною аварій, пов'язаних 3 великими вантажівками, також $є$ помилка водія вантажівки.[11] Ці дорожньо-транспортні пригоди в основному були пов'язані 3 некоректними діями та поведінкою водія за кермом, зумовленими відсутністю у водіїв вантажних автомобілів належних знань та навичок щодо належної практики управління великоваговим автотранспортним засобом, відволікання, низький загальний рівень майстерності та / або неадекватна поведінка водіння

На додаток до болю і смутку через травми або, навіть загибелі людей, ДТП за участю комерційних транспортних засобів, також неминуче призводять до втрати замовлень, зниженню довіри клієнтів та репутації компанії транспортного оператору, негайного виведення з експлуатації автотранспортного засобу для ремонту, або навіть його втрату, призупинення дії основних водіїв, втрата робочих днів через травмування водія, витрати на перепланування робіт, витрати на розслідування, страхування та оформлення документів, компенсації.

Одночасно проблема безпеки дорожнього руху і економічні втрати стали зростаючою турботою громадянського суспільства та урядів в усіх країнах світу. 3 цієї точки зору уваги заслуговує дослідження проведене МСАТ (Міжнародний Союз автомобільного Транспорту, Женева Швейцарія) сумісно з країнами Арабського регіону.[9]

Зазначені дослідження показують, що помилки водіїв комерційних вантажівок та їх неналежне поводження за кермом були відповідальні приблизно за 77\% всіх аварій у арабському регіоні. Варто зазначити, що така ситуація в арабському регіоні демонструє 
відсутність в даний час обов'язкової системи підтвердження кваліфікації професійних водіїв на автомобільного транспорті, і ця відсутність негативно впливає на стандарти безпеки та ефективності комерційних перевезень на автомобільному транспорті. Результати досліджень свідчать про те, що цифровий вираз цінності статистичного життя (VSL), a також вартість травм, що виникають внаслідок дорожньо-транспортних пригод, 3 урахуванням відсутності зростання ефективності або втраченої вигоди, яку отримали б автотранспортні компанії, становлять значну причину втрати багатства та добробуту для країн, які стали об'єктом цього дослідження. Доступні дані свідчать, що втрати ВВП склали $6,77 \%$ в Судані, 6,45\% в Іраку та 6,08\% в Джибуті. Збитки також є значними в Смені, Йорданії, Лівії та Лівані (6,02\%, 5,59\%, 5,19\% та 4,75\% відповідно). [9]

Основні наведені нижче, показники ефективності (KPI), показують зміни, які відбулися після введення тренувань водіїв:

- Середнє зменшення кількості аварій на 1 мільйон кілометрів на 46\%;

- в середньому на 30\% знижується річна вартість медичної допомоги (у випадках, що перевищують страхову суму);

- $25 \%$ скорочення людських днів, втрачених щорічно внаслідок травм водіїв;

- Скорочення в середньому на $48 \%$ втрат річних доходів 3 причини тривалого простою вантажівки, в результаті ДТП;

- Середнє скорочення річних витрат на ремонт парку внаслідок аварій на 17\% (у випадках, що перевищують страхову суму);

- 51\% скорочення річної кількості поставок пошкодженого через ДТП/вантажу;

- Скорочення в середньому на 55\% річних витрат на найм та навчання нових водіїв як заміни для потерпілих / відсутніх водіїв у результаті аварій.

Також у дослідженні було продемонстровано вплив тренувань на ефективність транспорту:

- Середньорічні порушення IVMS були зменшені на 58\%;

- Середнє споживання пального на кілометр скоротилось на 14\%;

- Середні річні заощадження на витрати шин зменшено на 8\%;

- Середні річні витрати на технічне обслуговування та ремонт на одиницю вантажу були зменшені на 20\%;

- Середньорічна кількість повідомлень про потенційно небезпечні випадки збільшилася на $112 \%$, що відображає поліпшення культури безпеки;

- Середньорічна кількість скарг клієнтів зменшилась на 52\%;

- Середньорічна кількість претензій клієнтів зменшилась на 58\%;

- Середньорічне співвідношення поставок пошкоджених вантажів до загальної кількості поставок скоротилось на $42 \%$.

Таким чином, дане дослідження демонструє, що внутрішні заходи, політика та практика, а також доступ до зовнішніх навчальних програм для водіїв вантажних автомобілів можуть мати широкий вплив на загальну продуктивність компанії, ефективність їі роботи, якість логістичних послуг.

Серед можливостей підвищення загального міжнародного індексу LPI України за рахунок покращення значення одного 3 показників формування LPI, a саме “Компетентність та якість логістичних послуг”, з використанням мінімальних витрат, можна розглядати провадження спеціальної інформаційної системи управління компетентністю/віртуального ресурсу, який дозволяє контролювати рівень професійної компетентності водіїв комерційного транспорту. Зазначеної мети можливо досягти шляхом покращення низки параметрів: компетентності з безпеки та надійності автоперевезень, 3 кріплення вантажів, 3 екологічного та раціонального керування автотранспортними засобами, забезпечити таймінг доставки вантажу, якість, надійність та ефективність послуг автоперевезень, сформувати позитивний імідж українських комерційних автотранспортних операторів. Для прикладу, згідно даних опитування автоперевізників, введення такої системи, у розробці якої автори приймають безпосередню участь, надасть можливість 
підвищити зазначений показник Компетентність та якість логістичних послуг” і як результат індекс ефективності логістики на 0,35 .

Очікувані результати від реалізації проекту: створення базової версії Реєстру водіїв, які здійснюють перевезення пасажирів та вантажів дозволить користувачам отримувати інформацію про професійних водіїв; контролюючому органу верифікувати кваліфікаційні картки водіїв, які засвідчують компетентність водія; пасажирам оцінити роботу водія та подати скаргу щодо якості отриманих послуг. Мінінфраструктури отримує можливість одержувати інформацію від контролюючих органів інших країн про водіїв, у яких є кваліфікаційна картка водія.

Кількісні показники досягнення результативності: отримання реципієнтом базової версії реєстру водіїв, забезпечить покращення матеріально-технічної бази та формування доступної та ефективної інфраструктури даних у сфері підтвердження професійної компетентності водіїв.

Якісні критерії досягнення результативності: впровадження Реєстру водіїв призведе до покращення якості надання транспортних послуг, наближення рівня їх надання до європейських стандартів, а також до підвищення рівня безпеки дорожнього руху та автоперевезень.

\section{Висновки}

Протягом декількох останніх років список процвітаючих країн першої десятки залишається відносно незмінним i, як правило, включає країни з високим рівнем доходу в Європі. 330 кращих, за показниками ефективності країн - $24 \epsilon$ членами OECP (OECD). Лідируючі країни мають досить високі показники якості та компетентності логістичних послуг. Такій рівень забезпечують, в тому числі, високі стандарти та професійна підготовка і компетентність персоналу автотранспортних компаній: менеджерів та водіїв.

В даний час відчувається брак фахівців з логістики як в розвинених країнах, так і в країнах, що розвиваються. Однак, розвинені країни мають потребу в більшій кількості так званих "синіх комірців", тобто працівників фізичної праці, таких як водії вантажівок, в той час як країни, що розвиваються шукають більше працівників управлінського рівня.

Професійність та компетентність ..дозволить оптимізувати алгоритм роботи АТП, , знизити статистику ДТП, порушень національного та м\н законодавства країн ЄС, рівень штрафних санкцій та мінімізувати витрати на перевезення, підвисити ефективність i безпеку переміщення товарів і пасажирів, якість автотранспортних перевезень зокрема i логістичних послуг в цілому, покращити імідж України і відповідно інвестиційну і бізнес привабливість, збільшити вантожопотки, та як результат надходження у бюджет України, що позитивно вплине на міжнародний рейтинг і індекси країни .

Все більше країн розглядають загрози кібербезпеки як ризик для логістичних ланцюжків постачань. I впровадження інтелектуальних систем на транспорті дозволяє доволі успішно мінімізувати такі ризики та підвищувати безпеку перевезень товарів та пасажирів. Проте, в той час як серед країн з високим рівнем доходів - 78\% збільшили свою готовність реагування на виклики сучасності, тільки $26 \%$ країн 3 низьким рівнем доходу зробили аналогічні кроки.

Політики і зацікавлені сторони у кожній країні мають справу з широким спектром політик і стратегій. Зростаючі проблеми сучасності передбачають просторове планування; екологічну, соціальну та економічну стабільність розвитку ланцюжка поставок; розвинення професійної компетентності, навичок та ресурсів для їх здобуття та навчання; стійкість ланцюжка поставок до збоїв ринкових механізмів, порушень процесів поставок, стихійного лиха, інших перебоїв та загроз (фізичних або цифрових),

Тож не дивно, що ефективний логістичний сектор в даний час визнається майже повсюдно в якості одного 3 основних інструментів реалізації економічного розвитку. Оскільки, як підтверджують вищенаведені дослідження, впровадження більш ефективної 
транспортної політики, цілком закономірно веде до підвищення ефективності логістики. Така політика охоплює, наприклад, регулюючі послуги; здійснення контролю, особливо для міжнародних товарів; підвищення якості державно-приватного партнерства (ДПП); забезпечення розвиненої транспортної інфраструктури в тому числі за рахунок впровадження інтелектуальних систем на автомобільному транспорті, сучасних інформаційних ресурсів, компетентності.

\section{Список використаних джерел}

1. OECD (2019), [Статистика міжнародних вантажоперевезень та викидів CO2 до 2050p OECD], Публікація OECD, URL:https://www.oecd-ilibrary.org , дата звернення $15 / 02 / 2019$

2. OECD/ITF - (2015), Kauppila, J. Транспорт і торгівля: [3'єднуючи континенти], семінар KOTI-ITF, [Міжнародні вантажні перевезення до 2050 року], 24 Березня 2015, Сеул URL:https://www.itf-oecd.org, дата звернення 15/02/2019

3. ITF(2017), Транспортний Прогноз ITF 2017, публікація OECD, Париж, URL:https://doi.org/10.1787/717c9f45-ru., дата звернення 18/02/2019

4. Мішель Акяро, Алан Маккинон, Логістичний університет Кюне (KLU), Гамбург, Німеччина, Стаття 2013 року. [Ефективна інфраструктура внутрішнього транспорту та послуги для великих контейнерних портів]

URL:http://www.internationaltransportforum.org/jtrc/DiscussionPapers/jtrcpapers.html p11-12 дата звернення 25/01/2020

5. Нyperloop - новий засіб наземного транспорту, який може перевозити пасажирів та вантажів зі швидкістю понад 1000 км/год у трубах низького тиску. Вантажні перевезення. Пасажирські перевезення. URL:https://zeleros.com/hyperloop/ дата звернення 30/02/2019

6. Видання Світового банку. Міжнародний скорекард країни: Україна 2018

URL:https://lpi.worldbank.org/international/scorecard/radar/254/C/UKR/2018\#chartarea дата звернення 02.02.2019

7. Видання Світового банку. Вітчизняний LPI. URL: https://lpi.worldbank.org/Domestic LPI, звернення 02.02.2019

8. Світовий банк і Університет Турку Жан- Франсуа Арвіс, Лаура Оджала, Крістіна Відерер, Анасуя Радж, Бен Шеперд, Карлигаш Дайрабаєва, Туомас Кікуська [Підключення до конкуренції 2018. Торгівельна логістика в глобальній економіці Індекс ефективності логістики та її показники.]С 2018 Міжнародний банк реконструкції та розвитку / Світовий банк 1818 H Street NW Вашингтон, округ Колумбія, 20433/The World Bank 1818 H Street NW Washington, DC 20433 URL: https://openknowledge.worldbank.org/bitstream/handle/10986/29971/LPI2018.pdf дата звернення 15/04/2019

9. Видання МСАТ. Заключний звіт дослідження 2016. Вплив професійної підготовки на комерційних водіїв / вантажних в арабському регіоні. URL: https://www.iru.org/sites/default/files/2016-

10/FINAL\%20REPORT\%20EN\%202016\%20web.pdf дата звернення 02.01.2020 pages 4-6.

10. ETAC, (2007). [Свропейське дослідження причин випадків ДТП]: дата звернення 20/01/2020

URL: https://previouswww.iru.org/cmsfilesystem-action?file=mixpublications/2007_ETACstudy.pdf

11. LTCCS, Дослідження причинності аварій за участю великих вантажівок: початковий огляд: URL:http://www-nrd.nhtsa.dot.gov/ Pubs/810646.pdf дата звернення 20/01/2020

12. Світовий банк [Індекс ефективності логістики], URL:https://lpi.worldbank.org,дата звернення 02.05.2019

13. Світовий банк. [Особливість історії 2018. Від частин до продуктів: Чому торгова логістика має значення] URL:http://www.worldbank.org/ дата звернення 20/08/2019 
14. Прокудін Г.С., Дудник О.С., Чупайленко О.А. [Інтеграція транспортної системи України в світову транспортну систему.]//Науковий вісник Ужгородського національного університету. 2015, Вип 4.

15. Процик О.П., Корчменюк С.В. [Напрямки удосконалення результуючих показників ефективності за рахунок покращення функціонування транспортної системи].// Управління проектами, системний аналіз і логістика - К.: НТУ - 2015. - Вип.15

16. Світовий банк. [Спрощення торгівлі та логістика. Сприяння торгівлі на кордоні, за кордоном та за його межами] URL: http://www.worldbank.org/en/topic/trade-facilitationand-logistics дата звернення 02.02.2019

17. Девід Банністер та Домінік Стід, [Зниження інтенсивності транспорту] Європейський журнал досліджень транспорту та інфраструктури 2 (3), 2002, 161-178, дата звернення; 10.02.20192(3), 2002,

URL:https://www.researchgate.net/publication/27348550_Reducing_transport_intensity

18. Шраменко Н.Ю. Підвищення якості логістичного сервісу вантажного терміналу / Шраменко Н.Ю. // Восточноевропейский журнал передовых технологий: сб. науч. тр. 2010. - Вып. 1/4(43). - С. 55 - 57.

19. Шраменко Н.Ю. Разработка имитационной модели функционирования грузового терминального комплекса / Шраменко Н.Ю. / Автомобильный транспорт: сб. науч. тр.Харків: ХНАДУ, 2010. - Вип. 27 - С. 77-82.

20. Шраменко Н.Ю. Вплив тривалості митного оформлення на строк доставки вантажів у міжнародному сполученні / Шраменко Н.Ю. / Вісник Академії митної служби України. - Дніпропетровськ: 2012. - № 1 (47) - С.69-75.

21. Карий О. І., Подвальна Г. В., [Логістична Інфраструктура України у Світових Рейтингах] Національний університет «Львівська політехніка» 2017 дата звернення 20.01.2020

Url:http://science.lpnu.ua/sites/default/files/journalpaper/2018/mar/9644/ilovepdfcom-41-49.pdf

22. Графік 1. Оцінка Індексу Ефективності Логістики України 2018, карта країни

23. Таблиця даних 1. Показники .Індексу Ефективності Логістики Україна 2007$2016 \mathrm{p}$

24. Графік 2. Рівень розвитку логістики України 2018p.

25. Таблиця даних 2. Показники .Індексу Ефективності Логістики України 2018p

26. Графік 3. Україна у порівнянні з лідером региону за ефіективністю (Німеччина) за 2007-2018p.

27. Таблиця даних 3. Показники LPI Україна і Німеччина за 2007-2018p.

28. Графік 4. Світовий Рейтинг LPI 2018

29. Таблиця даних 4. Україна в Світовому Рейтингу LPI 2018 .

30. Таблиця даних 5. Показники компетентності та якості логістичних послуг за 2018 p.

\section{References}

1. OECD (2019), OECD Statistics on International freight and CO2 emissions to 2050, OECD Publishing, URL:https://www.oecd-ilibrary.org/ available 15/02/2019

2. OECD/ITF - (2015), Transport and Trade: [Connecting Continents] (24 March 2015, Seoul) Kauppila, J. (2015), "International Freight to 2050", presented at the KOTI-ITF seminar, Seoul. URL:https://www.itf-oecd.org, available 15/02/2019

3. ITF (2017), ITF Transport Outlook 2017, OECD Publishing, Paris, URL:https://doi.org/10.1787/717c9f45-ru. available 18/02/2019

4. Michele Acciaro, Alan McKinnon The Kühne Logistics University (KLU), Hamburg, Germany, Discussion paper 2013. Efficient Hinterland Transport Infrastructure and Services for Large

Container

Ports 
URL:http://www.internationaltransportforum.org/jtrc/DiscussionPapers/jtrcpapers.html p11-12 date $25 / 01 / 2020$

5. Hyperloop is a new mean of ground transportation that can carry passenger and cargo at speeds over $1000 \mathrm{~km} / \mathrm{h}$ inside low-pressure tubes. Freight. Passenger URL:https://zeleros.com/hyperloop/ available 25/01/2019

6. World bank publication. INTERNATIONAL SCORECARD. Country Score Card: Ukraine 2018

https://lpi.worldbank.org/international/scorecard/radar/254/C/UKR/2018\#chartarea available 02.02 .2019

7. World bank publication. Domestic LPI. URL: https://lpi.worldbank.org/domestic LPI date, available 02.02.2019

8. The World Bank, Turku university [Connecting to Compete 2018. Trade Logistics in the Global Economy The Logistics Performance Index and Its Indicators.]Jean-François Arvis, Lauri Ojala, Christina Wiederer, Ben Shepherd, Anasuya Raj, Karlygash Dairabayeva, Tuomas Kiiski (C) 2018 The International Bank for Reconstruction and Development/The World Bank 1818 H Street NW Washington, DC 20433, available 15/04/2019

URL: https://openknowledge.worldbank.org/bitstream/handle/10986/29971/LPI2018.pdf

9. IRU publication. Final report research study 2016. The impact of professional training on commercial/freight drivers in the Arab region. URL: https://www.iru.org/sites/default/files/2016-

10/FINAL\%20REPORT\%20EN\%202016\%20web.pdf available 02.01.2020 pages 4-6.

10. ETAC, (2007). European Truck Accident Causation Study: Available 20/01/2020

URL:: https://previouswww.iru.org/cmsfilesystem-action?file=mixpublications/2007_ETACstudy.pdf

11. LTCCS, Large-Truck Crash Causation Study: An initial Overview:: URLhttp://wwwnrd.nhtsa.dot.gov/ Pubs/810646.pdf Available 20/01/2020

12. Worldbank About Logistics Performance Index, URL:https://lpi.worldbank.org, available 02.05.2019

13. Feature Story 2018.From parts to products:Why trade logistics matter URL:http://www.worldbank.org available 20/08/2019

14. Prokudin H.S., Dudnik O.S, Chupaylenko O.A. Ukraine transport system integration into the global transport system.// Scientific Bulletin of Uzhgorod National University. 2015, Vol 4.

15. Protsyk O.P., Korchmeniuk S.V. Areas of improvement resulting indicators efficiency by enhancement the functioning of the transport system// Project Management, System Analysis and Logistics - K .: NTU - 2015. - Issue 4

16. The world Bank. Trade Facilitation And Logistics. Facilitating Trade At The Border, Behind The Border, And Beyond URL: http://www.worldbank.org available 02.02.2019

17. David Bannister and Dominic Stead, [Reducing transport intensity] European Journal of Transport and Infrastructure Research 2(3), 2002, 161-178, дата звернення 10.02.2019

18. Shramenko N.Yu. Improving the quality of logistic service of cargo terminal / Eastern European Journal of Advanced Technologies: Sat. scientific tr. - 2010. - Issue. 1/4 (43). - C. 55 57.

19. Shramenko N.Yu. Development of a simulation model of the functioning of the cargo terminal complex / Motor transport: cb. scientific tr.- Kharkiv: KHNADU, 2010. - VIP. 27 - S. $77-82$.

20. Shramenko N.Yu. Influence of the duration of customs clearance on the time of delivery of goods in international traffic / Bulletin of the Academy of Customs Service of Ukraine. - Dnepropetrovsk: 2012. - № 1 (47) - P.69-75.

21. Karyy O, Podvalna G, [Logistics Infrastructure of Ukraine in International ranking] National University "Lviv Polytechnic" 2017 accessed 20/01/2020Chart 1. Ukraine .Logistic 
Технічний сервіс агропромислового, лісового та транспортного комплексів

Technical service of agriculture, forestry and transport №18' 2020

Performance Index Country Score card 2018.

Url:http://science.lpnu.ua/sites/default/files/journal-paper/2018/mar/9644/ilovepdfcom-41-49.pdf

22. Data table 1. Subindicators of Logistic Performance Index for Ukraine 2007-2016

23. Chart 2 Logistics development level of Ukraine 2018

24. Data table 2. Subindicators of Logistic Performance Index for Ukraine 2018

25. Chart 3. Ukraine against top performer in region (Germany) for 2007-2018.

26. Data table 3. LPI Subindicators of Ukraine and Germany for 2007-2018.

27. Chart 4. World LPI Ranking 2018.

28. Data table 4. Ukraine in world LPI Ranking 2018.

29. Data table 5. Logistics services competence and quality subindicators 2018. 